\title{
ГОСУДАРСТВЕННЫЕ ПРОГРАММЫ, НАЦИОНАЛЬНЫЕ ПРОЕКТЫ И ОЦЕНОЧНЫЕ ПРОЦЕДУРЫ КАК ИНСТРУМЕНТЫ ПРАВОВОГО РЕГУЛИРОВАНИЯ ФИНАНСОВОЙ ПОЛИТИКИ В СУБЪЕКТАХ РОССИЙСКОЙ ФЕДЕРАЦИИ
}

\author{
(c) 2020 Щукина Татьяна Владимировна \\ доктор юридических наук, доцент \\ ведущий научный сотрудник сектора административного права и процесса \\ Института государства и права РАН, Россия, Москва
}

\begin{abstract}
Предметом настоящей статьи выступает исследование новых форм и инструментов финансовой политики в субъектах Российской Федерации. Тема статьи отражает вопросы интеграции государственных программ, национальных проектов и оценочных процедур в современной финансовой политике. Целью настоящей статьи являются выявление особенностей интеграции новых методов и инструментов финансовой политики на современном этапе социально-экономического развития регионов, места и роли государства в этом процессе. Методологию данной работы составили сравнительный, формально-юридический, аналитический методы. Результаты работы - это формулирование роли и содержания новых интеграционных инструментов правового регулирования финансовой политики. Область применения результатов работы включает в себя финансовую, бюджетную, налоговую политику.
\end{abstract}

Ключевые слова: государственные программы, национальные проекты, оценочные процедуры, оценочные процедуры.

Регламентация финансовых правоотношений в субъектах Российской Федерации осуществляется с помощью федеральных законов, законов субъектов Российской Федерации, государственных программ и национальных проектов. К числу законодательных актов субъекта Российской Федерации в сфере регулирования финансовой политики относятся: «О бюджетном процессе», «О региональных налогах», «О налогах и особенностях налогообложения отдельных категорий налогоплательщиков», «O налоговой политике», «О межбюджетных трансфертах и нормативах отчислений доходов в местные бюджеты» и др. [1]

Современное законодательство о бюджете и бюджетном процессе, о налогах субъектов Российской Федерации унифицировано и единообразно в отличие от аналогичного законодательства начала 90-х годов. Оно сходно во всех субъектах Российской Федерации и по количественному и содержательному показателям [2], по времени вступления в силу, хотя в некоторых случаях учитывает региональные особенности. На наш взгляд, это связано с систематичным выстраиванием единой бюджетной и налоговой политики федерального центра, строгой реали- зацией Бюджетного кодекса Российской Федерации [3] и Налогового кодекса Российской Федерации [4].

Особое внимание уделяется региональными законодателями формированию законов о бюджете и бюджетном процессе субъекта Российской Федерации. Бюджеты субъектов Российской Федерации разрабатываются и принимаются сроком на 1 год. Для вышеуказанных законодательных актов присущ ярко выраженный социальный характер расходной части регионального бюджета. Отметим, что государственные программы субъектов Российской Федерации выступают действенными инструментами социальной адаптации финансового механизма в условиях нестабильной экономической ситуации. Многие государственные программы субъекты Российской Федерации в состоянии профинансировать самостоятельно, не прибегая к федеральной помощи.

Социальные мандаты субъекты Российской Федерации реализуют и через национальные проекты. Распределение основных финансовых ресурсов в субъектах Российской Федерации осуществляется согласно национальным целям: финансирование инновационных проектов, раз- 
витие инфраструктуры и цифровой экономики, здравоохранения, совершенствование системы образования и социальной политики, включая развитие культуры, искусства, физической культуры и спорта; охрану окружающей природной среды. Хотя, немалую долю в бюджетах субъектов Российской Федерации до сих пор составляют расходы на государственное и муниципальное управление.

Принятие сбалансированного бюджета субъекта Российской Федерации позволяет в первую очередь обеспечивать достаточный объем финансирования для разработки и внедрения большого количества социальных проектов. Это обеспечивает выполнение главной задачи исполнительной власти - создание комфортной жизнедеятельности населения на территории субъекта Российской Федерации. В это связи государство должно изыскивать и рационально использовать необходимые ресурсы. Направления совершенствования социальной и экономической защищённости граждан субъекта Российской Федерации отражаются, как правило, в государственных программах и национальных проектах.

Модернизация финансовой, бюджетной политики субъектов Российской Федерации будет проходить до 2030 года на основе Прогноза социально-экономического развития Российской Федерации на период до 2036 года, Бюджетного прогноза Российской Федерации на период до 2036 года и по стратегиям социальноэкономического развития субъектов Российской Федерации, государственным программам, разрабатываемым субъектами Российской Федерации. Думается, на современном этапе следует обращать внимание на результаты управления финансами и эффективное внедрение механизма регуляторной гильотины, наделяя четкими полномочиями государственные органы, осуществляющие финансовый контроль и определяющие сущность финансовой политики. В связи с чем, усиливается роль оценочных процедур при реализации финансовой политики государства.

Целью оценочных процедур является гармонизация взаимодействия объектов и субъектов публичного управления. Оценочные процедуры в деятельности органов исполнительной власти сопровождаются разработкой разнообразных рейтингов [5], сводов лучших практик [6], перечней, мониторингов [7], индексов и т.п. Подобная управленческая деятельность имеет аналитический, обобщающий характер, способствующий формированию реалистичного облика управления в соответствующей области и дальнейшему улучшению его качества и повышению эффективности. Оценку могут производить специально уполномоченные субъекты [8], профессиональные объединения [9] и другие субъекты в соответствии с требованиями законодательства. Порядок и основания проведения официальных оценочных процедур закрепляется в нормативных правовых актах.

Под экспертной процедурой, по мнению автора, следует понимать официально установленную, последовательную и упорядоченную совокупность действий по оценке качества и эффективности властно-распорядительного воздействия государства в соответствующей области публичного управления, в сфере правоотношений, государственных полномочий или законодательства для последующего вынесения экспертного заключения. Области властнораспорядительного воздействия государства разнообразны и закрепляются в законодательстве. Результатом экспертных процедур в деятельности органов исполнительной власти выступает достоверное, обоснованное экспертное заключение. Как правило, в качестве экспертов выступают лица, обладающие специальными познаниями в области проведения экспертизы, к этим лицам предъявляются определенные требования к их компетентности, за исключением общественной экспертизы. Различаются в действующем законодательстве независимая экспертиза и экспертиза уполномоченного органа исполнительной власти.

Перечислим некоторые виды экспертных процедур универсального характера, осуществляемых в деятельности большинства органов исполнительной власти:

- антикоррупционная экспертиза правовых актов и их проектов;

- общественная экспертиза;

- экспертиза при проведении конкурсов, грантов, субсидий и т.п.;

- экспертиза национальных проектов [10];

- экспертиза проектов государственных программ;

- экспертиза административных регламентов;

- экспертиза иных нормативных правовых актов федеральных органов исполнительной 
власти.

Выделяются также отраслевые экспертные процедуры: экспертиза качества образования, экологическая экспертиза, экспертиза проектной документации, экспертиза промышленной безопасности и т.п.

Отметим некоторые из них, экспертиза проектов региональных государственных программ [11]. Данный вид экспертизы осуществляется уполномоченными органами исполнительной власти (главным распорядителем средств федерального бюджета и федеральными органами исполнительной власти - участниками государственной программы). Предметом экспертизы является соответствие программы задачам Стратегии государственной национальной политики Российской Федерации на период до 2025 года.

Экспертиза порядка осуществления контроля за переданными полномочиями [12]. Проект порядка осуществления контроля за переданными полномочиями, а также изменения, которые вносятся в порядок осуществления контроля за переданными полномочиями, подлежат экспертизе в Министерстве юстиции РФ, которая проводится в течение 7 дней. Предметом такой экспертизы является оценка:

- соответствия структуры порядка осуществления контроля за переданными полномочиями;

- полноты описания в порядке осуществления контроля за переданными полномочиями прав и обязанностей должностных лиц федерального органа исполнительной власти и органов государственной власти субъектов РФ, а также состава, последовательности и сроков выполнения административных процедур, требований к их выполнению;

- оптимизации порядка осуществления контроля за переданными полномочиями, включая упорядочение административных процедур, сокращение административных процедур и сроков их осуществления, а также устранение избыточных административных процедур.

\section{Библиографический список}

1. о бюджетном процессе в Челябинской области: закон Челябинской области № 205-30 от 27 сентября 2007 года // Южноуральская панорама. 2007. 19 октября; Бюджетный кодекс РТ от 29 мая 2004 г. № 35-3РТ; Об областном бюджете на 2020 год и на плановый период 2021 и 2022 годов: закон Саратовской области от 26 ноября 2019 г. № 130-3СО; О региональных налогах и некоторых вопросах налогообложения в Ростовской области: областной закон Ростовской области от 10 мая 2012 г. № 843-3С; О налогах и особенностях налогообложения отдельных категорий налогоплательщиков в Новосибирской области: закон Новосибирской области от 16 октября 2003 г. № $142-03$

2. О дополнительных основаниях признания безнадежными к взысканию недоимки, задолженности по пеням и штрафам по региональным налогам: закон Вологодской области от 9 июля 2013 г. № 3113-О3 // Красный Север. 2013. 13 июля

3. Собрание законодательства Российской Федерации. 1998. № 31. Ст. 3823; 1998. № 31. Ст. 3824

4. Собрание законодательства Российской Федерации. 2000. № 32. Ст. 3340

5. Рейтинг инвестиционного климата в субъектах РФ, рейтинг эффективности деятельности губернаторов и другие

6. Свод лучших практик в области управления проектами, в области ОРВ и ОФВ нормативных правовых актов, в области сельскохозяйственной кооперации, в области кластерного развития промышленности и т.п.

7. Концепция открытости федеральных органов исполнительной власти, утв. распоряжением Правительства РФ от 30 января 2014 г. № 93-р

8. Минэкономразвития РФ

9. Опросы предпринимателей АСИ

10. Об организации проектной деятельности в Правительстве Российской Федерации: постановление Правительства РФ от 15 октября 2016 г. № 1050

11. Об утверждении государственной программы Российской Федерации «Реализация государственной национальной политики»: постановление Правительства РФ от 29 декабря 2016 г. № 1532 // Собр. законодательства Рос. Федерации. 2017. № 2 (часть I). Ст. 361 
12. Об утверждении Правил подготовки нормативных правовых актов федеральных органов исполнительной власти, устанавливающих порядок осуществления контроля за эффективностью и качеством осуществления органами государственной власти субъектов Российской Федерации переданных им для осуществления полномочий Российской Федерации по предметам ведения Российской Федерации и (или) предметам совместного ведения Российской Федерации и субъектов Российской Федерации: постановление Правительства РФ от 3 июля 2018 г. № 780 // Собр. законодательства Рос. Федерации. 2018. № 28. Ст. 4240. 